\title{
Phenylketonuria: Protein content and amino acids profile of dishes for phenylketonuric patients. The relevance of phenylalanine
}

\author{
Filipa B. Pimentel, Rita C. Alves, Anabela S.G. Costa, Duarte Torres, Manuela F. Almeida, \\ M. Beatriz P.P. Oliveira
}

\begin{abstract}
Phenylketonuria is an inborn error of metabolism, involving, in most cases, a deficient activity of phenylalanine hydroxylase. Neonatal diagnosis and a prompt special diet (low phenylalanine and natural-protein restricted diets) are essential to the treatment. The lack of data concerning phenylalanine contents of processed foodstuffs is an additional limitation for an already very restrictive diet.

Our goals were to quantify protein (Kjeldahl method) and amino acid (18) content (HPLC/fluorescence) in 16 dishes specifically conceived for phenylketonuric patients, and compare the most relevant results with those of several international food composition databases.

As might be expected, all the meals contained low protein levels $(0.67-3.15 \mathrm{~g} / 100 \mathrm{~g})$ with the highest ones occurring in boiled rice and potatoes. These foods also contained the highest amounts of phenylal- anine ( 158.51 and $62.65 \mathrm{mg} / 100 \mathrm{~g}$, respectively). In contrast to the other amino acids, it was possible to predict phenylalanine content based on protein alone. Slight deviations were observed when comparing results with the different food composition databases.
\end{abstract}

\section{Keywords}

Phenylketonuria, Low protein foods, Protein content, Amino acids, Phenylalanine

\section{Introduction}

Phenylketonuria (PKU) was first described in 1934 by Asbörn Föling (Centerwall \& Centerwall, 2000). It is an autosomal recessive inborn error of the metabolism that occurs due to mutations in the gene that codifies the phenylalanine hydroxylase (PAH) (BelangerQuintana, Burlina, Harding, \& Muntau, 2011; Scriver \& Kaufman, 2001; Smith \& Lee, 2000), which is responsible for converting dietary phenylalanine (Phe) into tyrosine (Tyr) in the liver. The location and type of mutation within the gene determine the severity of the phenotype (Mallolas et al., 1999). A decrease of PAH concentration and/or lower enzyme activity results in persistent elevated Phe blood and tissue concentrations, with potential toxic effects, particularly for the developmental brain (Blau, van Spronsen, \& Levy, 2010; de Groot, Hoeksma, Blau, Reijngoud, \& van Spronsen, 2010; van Spronsen \& Enns, 2010). Early diagnosis in the neonatal period, with a screening program (Blau, Hennermann, Langenbeck,
\& Lichter-Konecki, 2011), and prompt dietary treatment are essential to prevent severe mental retardation and to achieve a good patient prognosis (Blau et al., 2010; de Groot et al., 2010). Indeed, patients with late diagnose and/or poor metabolic control tend to evidence signs of cognitive dysfunction, namely, developmental delay, progressive intellectual impairment, seizures, attention deficit/hyperactivity disorder, decreased autonomy, behavioral problems, such as aggression, anxiety or social isolation (Demirkol, Gizewska, Giovannini, \& Walter, 2011; Rocha \& Martel, 2009; Scriver \& Kaufman, 2001). Untreated patients may also present other clinical signs such as a mousy odour, eczema, reduced pigmentation, reduced growth and microcephaly (Rocha \& Martel, 2009).

Although some new therapeutic approaches have been studied in order to improve the quality of life of PKU patients (as neutral amino acids, glycomacropeptide, tetrahydrobiopterin, Phe ammonia lyase or gene therapy) (Blau et al., 2010; Feillet \& Agostoni, 2010; Rocha \& Martel, 2009; van Spronsen \& Enns, 2010), dietary management remains the mainstay of treatment (MacDonald, Rocha, van Rijn, \& Feillet, 2011; van Spronsen \& Enns, 2010). Nutritional guidelines and statements vary between countries (Demirkol et al., 2011), but low protein and Phe-restricted diet 

are common (Feillet \& Agostoni, 2010) as well as the need to continue the treatment throughout life. In order to limit the intake of Phe, dietary management of PKU patients restrict natural-protein food (Feillet \& Agostoni, 2010). Therefore, based on nutritional recommendations and on PKU patients' individual tolerances, dietary treatment includes protein substitutes (Phe-free AA mixtures) and a wide range of low protein products (like bread, biscuits, cereals, pasta, flour, milk substitutes, cheese substitutes, egg substitutes, soups, candies, amongst others) to make up the energy needs of the PKU patients. In addition to these, the diet also incorporates strictly controlled amounts of natural foods, essentially fruits, vegetables and other natural foods or food products with low protein content (Bremer, Anninos, \& Schulz, 1996; Weetch \& MacDonald, 2006).

It is, therefore, of utmost importance to know the nutritional information of natural and processed food products included in these patients' diet, especially protein and Phe. It is often reported there is scarcity of information about Phe content particularly in food composition databases (FCD). In Europe, for example in UK's or Denmark's FCD, when available, Phe contents often concerns raw foods and, rarely, cooked composite meals. Some countries, as Portugal, do not have the complete aminogram of foods available in national FCD. In these cases, international data has to be consulted. Nonetheless, it is important to be aware that many factors (soil type, season, geography, type of processing.) may influence nutrient composition of foods and data cannot always be extrapolated from one country to another.

The aim of this work was to study the protein and amino acid contents of 16 low protein dishes selected from a list of recipes specifically planned for PKU patients (Almeida, 1995, 2001) and prepared with special ingredients acquired in Portugal, as well as to compare the most relevant results (protein and Phe) with the information described in several FCD (when available).

\section{Materials and methods}

\subsection{Standards and reagents}

Dansyl chloride and amino acid standards (L-alanine (Ala), $\mathrm{L}^{-}$ arginine (Arg), L-asparagine (Asn), L-aspartic acid (Asp), L-glutamic acid (Glu), L-cysteine (Cys), L-glycine (Gly), L-glutamine (Gln), Lhistidine (His), L-isoleucine (Ile), L-leucine (Leu), L-lysine (Lys), $\mathrm{L}^{-}$ methionine (Met), L-phenylalanine (Phe), L-ornitine (Orn), L-proline (Pro), L-serine (Ser), L-threonine (Thr), L-tryptophane (Trp), L-tyrosine (Tyr) and L-valine (Val)), as well as the internal standard L-norleucine (Nor) were all obtained from Sigma (St. Louis, MO, USA).

Purified water was obtained from a Milli-Q water purification system (Millipore, Bedford, MA, USA). HPLC-grade acetonitrile and N,N-dimethylformamide (DMF) were from Fluka (Madrid, Spain). All other chemicals used were of analytical grade.

\subsection{Samples}

Most of the 16 low protein dishes were selected from a list of recipes specifically planned for PKU patients (Almeida, 1995, 2001), which included soups, main courses, desserts and other daily basic foods, as described in Table 1. Regular ingredients were bought in local supermarkets. Dietetic low protein and low Phe products - egg substitute, low protein chocolate candies, low protein flour, low protein milk substitute, low protein pasta, low protein shortbread biscuits and low protein vermicelli - were kindly provided by Centro de Genética Médica Doutor Jacinto de Magalhães, INSAIP, Porto, Portugal.

\subsection{Sample preparation}

The dishes were prepared and cooked according to the instructions (Almeida, 1995, 2001) using domestic scale utensils and equipment. After being cooked, the food samples were mashed until completely homogenised (Moulinex Classical A320R1, Moulinex, France) and protein content determined immediately. Samples were kept frozen at $-200 \mathrm{C}$ until analysis (total amino acids).

\subsection{Protein determination}

Protein content was determined using the Kjeldahl method (Büchi Labortechnik AG, 2007). Briefly, $1 \mathrm{~g}$ of each homogenised sample was digested with $96 \%$ sulfuric acid, using a catalytic mixture. Digestion was performed in a Büchi ${ }^{\circledR}$ apparatus (Automat K-438, Büchi Labortechnik AG, Swiss). The ammonia formed was distilled and collected in a solution of boric acid (Distillation Unit K-360, Büchi ${ }^{\circledR}$, Büchi Labortechnik AG, Swiss), which was then titrated with sulfuric acid. In this way, the nitrogen content of the samples was determined. Protein content was calculated using the conversion factor 6.25 (Tontisirin, MacLean, \& Warwick, 2003). Analyses were performed in duplicate.

\subsection{Amino acids determination}

\subsubsection{Hydrolysis}

The acidic hydrolysis used for the determination of the amino acids was performed as described elsewhere (Fountoulakis \& Lahm, 1998; Paramas, Barez, Marcos, Garcia-Villanova, \& Sanchez, 2006) with slight modifications. Briefly, $1 \mathrm{~g}$ of sample was weighted into a screw-cap tube to which $3 \mathrm{ml}$ of $6 \mathrm{~mol} \mathrm{~L}^{-1} \mathrm{HCl}$ were added. Oxygen was removed using a $\mathrm{N}_{2}$ stream. The tubes were tightly capped and heated at $1100 \mathrm{C}$ for $24 \mathrm{~h}$. The extracts were neutralized with $12 \mathrm{~mol} \mathrm{~L}^{-1} \mathrm{KOH}$ to $\mathrm{pH} 7$.

The alkaline hydrolysis was performed to determine tryptophan content, as described by Yust et al. (Yust et al., 2004) with slight modifications. Briefly, $1 \mathrm{~g}$ of sample was weighted into a screw-cap tube to which $3 \mathrm{ml}$ of $4 \mathrm{~mol} \mathrm{~L}^{-1} \mathrm{KOH}$ were added. Oxygen was removed using a $\mathrm{N}_{2}$ stream. The tubes were capped and heated at $1100 \mathrm{C}$ for $4 \mathrm{~h}$. The extracts were neutralized with $12 \mathrm{~mol} \mathrm{~L}^{-1} \mathrm{HCl}$ to $\mathrm{pH} 7$.

Both procedures were carried out in triplicate.

\subsubsection{Derivatization}

Dansyl chloride derivatives were prepared, in duplicate, according to Navarro, Aristoy, \& Izquierdo (1984). Briefly, the hydrolysates obtained were centrifuged (Heraeus Sepatech Labofuge Ae, Haraeus Instruments, Germany) at $5000 \mathrm{rpm}$ for $5 \mathrm{~min}$. A supernatant aliquot (500 11) was transferred to a screw-cap tube and $500112 \mathrm{~mol} \mathrm{~L}^{-1}$ $\mathrm{Na}_{2} \mathrm{CO}_{3}$ added followed by 20011 dansyl chloride (2\%), 6011 norleucine $(4001 \mathrm{~g} / \mathrm{ml})$ and $1 \mathrm{ml}$ acetone (final $\mathrm{pH}$ between 9.5 and 10.5). The tubes were capped and heated to $1100 \mathrm{C}$ for $10 \mathrm{~min}$. After cooling to room temperature in the dark, and $1 \mathrm{ml}$ of the derivatized extract was centrifuged (Heraeus Sepatech Biofuge Pico, Haraeus Instruments, Germany) at 13,000 rpm for $5 \mathrm{~min}$. The supernatant was transferred into amber glass vials (Supelco, Bellefonte, PA, USA) and analysed by RP-HPLC/fluorescence.

\subsubsection{RP-HPLC/fluorescence analysis}

The chromatographic analysis was carried out in a HPLC integrated system equipped with an AS-950 automated injector, a PU-980 pump, and a FP-920 fluorescence detector (Jasco, Japan) programmed for excitation at 335 and emission at $514 \mathrm{~nm}$.

The chromatographic separation was achieved with a RP-Tracer Excel ODS-A column ( $5 \mathrm{~lm} ; 250 \times 4 \mathrm{~mm})$ from Teknokroma (Spain) operating at controlled temperature of 40 0C (Jasco CO2060 Plus, Jasco, Japan). 
Table 1

List of recipes and ingredients.

\begin{tabular}{|c|c|c|}
\hline Samples & Recipes & Ingredients \\
\hline \multicolumn{3}{|l|}{ Soups } \\
\hline 1 & Green bean soup & Water, potatoes, onions, tomatoes, white cabbage, potato starch, green beans, olive oil, salt \\
\hline 2 & Carrot soup & Water, carrots, onions, potatoes, potato starch, olive oil, salt \\
\hline \multicolumn{3}{|c|}{ Main courses } \\
\hline 3 & Low protein pasta with vegetables sauce & $\begin{array}{l}\text { Water, low protein pasta, spices (saffron, bay leaf and nutmeg, paprika), margarine, carrots, white cabbage, } \\
\text { fresh mushrooms, olive oil, garlic powder, tomato paste }\end{array}$ \\
\hline 4 & Roasted potatoes with vegetables & Potatoes, onions, carrots and garlic cloves, salt, parsley leafs, water, white wine, corn oil \\
\hline 5 & $\begin{array}{l}\text { Potatoes stuffed with a mixture of low protein bread, } \\
\text { mushrooms and garlic, cooked in tomato sauce }\end{array}$ & Water, potatoes, low protein bread, mushrooms, garlic, parsley, tomatoes, onions, corn starch, olive oil, salt \\
\hline 6 & 3 colour layer vegetables puree pie & $\begin{array}{l}\text { Water, carrots, artichokes, brussels sprouts, potatoes, corn starch, low protein milk substitute, margarine, } \\
\text { low protein bread dry breadcrumbs, Spices (nutmeg and paprika), dry parsley salt }\end{array}$ \\
\hline 7 & Onion pie & $\begin{array}{l}\text { Low protein flour, margarine, water, onions, carrots, mushrooms, olives, salt, garlic powder pepper, olive oil, } \\
\text { corn oil, corn starch, low protein milk substitute, dry parsley }\end{array}$ \\
\hline 8 & Mushroom croquettes & $\begin{array}{l}\text { Mushrooms, olive oil, salt, fresh parsley, corn starch, low protein milk substitute, margarine, nutmeg, egg } \\
\text { substitute, low protein bread crumbs }\end{array}$ \\
\hline 9 & Vegetable patties & $\begin{array}{l}\text { Water, corn oil, salt, low protein flour, onions, mushrooms, garlic, corn oil, carrots, boiled rice, fresh parsley, } \\
\text { olives, white wine }\end{array}$ \\
\hline \multicolumn{3}{|l|}{ Desserts } \\
\hline 10 & Biscuits cake & Low protein biscuits, sugar, instant coffee, water, butter \\
\hline 11 & Pineapple cake & $\begin{array}{l}\text { Low protein flour, baker's yeast, margarine, sugar, egg substitute, vanilla, water, margarine, liquid caramel, } \\
\text { pineapple. }\end{array}$ \\
\hline 12 & Sweet vermicelli & $\begin{array}{l}\text { Low protein milk substitute, lemon zest, vanilla extract, cinnamon, low protein vermicelli, sugar, egg } \\
\text { substitute }\end{array}$ \\
\hline \multicolumn{3}{|c|}{ Daily basic foods } \\
\hline 13 & Boiled rice & Water, rice \\
\hline 14 & Boiled potato & Water, potatoes \\
\hline 15 & Low protein bread & Low protein flour, salt, baker's yeast, water \\
\hline \multicolumn{3}{|l|}{ Others } \\
\hline 16 & Low protein homemade liquid yogurt & Corn starch, egg substitute, low protein milk substitute, natural yogurt \\
\hline
\end{tabular}

The gradient eluent system consisted of: A) acetonitrile; B) $\mathrm{K}_{2} \mathrm{HPO}_{4} 0.0185 \mathrm{~mol} \mathrm{~L}^{-1}$ with $4 \% \mathrm{DMF}$ and $0.1 \%$ of triethylamine (final pH rv2.5). The HPLC injection volume was 2011 and the flow rate was $1.1 \mathrm{ml} / \mathrm{min}$, using the following gradient: $0^{0} 17 \% \mathrm{~A}, 26^{0}$ $50 \% \mathrm{~A}, 28^{\circ} 50 \% \mathrm{~A}, 40^{\circ} 90 \% \mathrm{~A}$.

Chromatographic data were analysed using a Borwin-PDA Controller Software (JMBS, France). The amino acids were identified by retention time comparison with authentic standards and by standards addition (adding individual standards directly to sample aliquots). Quantification was performed on the basis of the internal standard method (basing the regression on the ratio of the analyte response to that of the internal standard) using fluorescence signals. A standard solution of $5001 \mathrm{~g} / \mathrm{ml}$ containing all the amino acids in study was prepared. Different dilutions were used for the calibration curves $(2501 \mathrm{~g} / \mathrm{ml}, 1001 \mathrm{~g} / \mathrm{ml}, 501 \mathrm{~g} / \mathrm{ml} ; 101 \mathrm{~g} / \mathrm{ml}$; $51 \mathrm{~g} / \mathrm{ml} ; 11 \mathrm{~g} / \mathrm{ml}$ ). Injections were performed in duplicate.

\subsection{Food composition databases}

We selected six FCD for nutrient content comparison, namely, the UK FCD - McCance and Widdowson's The Composition of Foods (Paul, McCance, Southgate, \& Russell, 1980); the Swedish Food Database (SFD) (National Food Agency, 2010); the Canadian Nutrient File (CNF) (Health Canada, 2010); the French FCD-Composition nutritionnelle des aliments - Table Ciqual 2012 (CIQUAL FFCT) (ANSES, 2012); the United States Department of Agriculture, National Nutrient Database (USDA NND) (United States Department of Agriculture \& Service, 2011); and the Portuguese FCD -Tabela da Composição de Alimentos Instituto Nacional de Saúde Doutor Ricardo Jorge (TCA INSA) (INSA, 2006).

\subsection{Statistics}

Statistical analyses were performed using STATISTICA for Windows (StatSoft, Inc., Tulsa, Okla) and Excel Microsoft Excel statistical software (Microsoft Office Excel 2003, Microsoft Corp. Redmond, WA). One-way ANOVA was used to compare two or more groups. Student's $t$ tests were used to discriminate between any two groups under consideration and post hoc Dunnett's test was performed for simultaneous paired comparisons. Simple linear regression analysis was used to evaluate the relationship between different compounds.

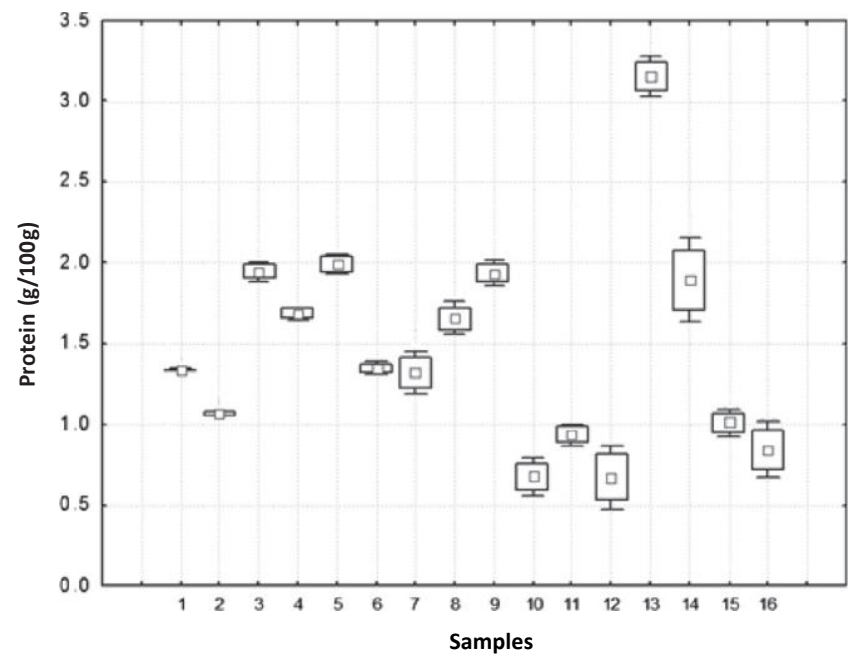

Fig. 1. Protein content $(\mathrm{g} / 100 \mathrm{~g})$ of the samples (mean \pm standard deviation). Legend: 1 - Green bean soup; 2 - carrot soup; 3 - low protein pasta with spiced vegetables sauce; 4 - roasted potatoes with vegetables; 5 - stuffed potato; $6-3$ colour layer vegetables puree pie; 7 - onion pie; 8 - mushroom croquettes; 9 vegetables patties; 10 - biscuits cake; 11 - pineapple cake; 12 - sweet vermicelli; 13 - boiled rice; 14 - boiled potato; 15 - low protein bread; 16 - low protein homemade liquid yogurt. 


\section{Results and discussion}

PKU patients need to follow a low protein diet but their diet still has to provide an adequate intake of essential amino acid (EAA) in order to guarantee a normal protein synthesis (Scriver \& Kaufman, 2001). The protein and amino acids content of 16 dishes prepared for PKU patients are shown in Fig. 1 and Table 2, respectively.

As expected, due to the type of ingredients used, all the meals had low protein content $(0.7-3.1 \mathrm{~g} / 100 \mathrm{~g})$. The highest amount (3.1 g/100 g) was observed in boiled rice (sample 13). No significant differences $(p>0.05)$ were found between stuffed potatoes $(2.0 \mathrm{~g} / 100 \mathrm{~g})$, boiled potatoes $(1.9 \mathrm{~g} / 100 \mathrm{~g})$, vegetables patties $(1.9 \mathrm{~g} / 100 \mathrm{~g})$ and pasta with spiced vegetables sauce $(1.9 \mathrm{~g} /$ $100 \mathrm{~g}$ ). The lower protein content found in roasted potatoes with vegetables compared with other potato dishes analysed was most likely because of the relative proportion of vegetables, which were responsible for a (slight) dilution effect. The lowest protein content was found in two desserts: biscuits cake and sweet vermicelli (0.7 g/100 g each).

As previously stated, dietary management of PKU patients restricts Phe intake. However, this is an EAA and it cannot be totally excluded from the diet, as this could limit protein synthesis. Moreover, Phe is a Tyr precursor, usually a non-EAA, required for the synthesis of several important neurotransmitters like serotonin, dopamine and noradrenalin (Smith \& Lee, 2000), thyroxin and melanin skin pigments (MacDonald et al., 2011). Consequently, for these individuals, Tyr is an EAA. Therefore, although PKU patients need to follow a low protein diet, it still has to provide an adequate intake of Tyr and other EAA (Scriver \& Kaufman, 2001). Commonly, the major source of protein intake comes from Phe-free and Tyrenriched amino acid products (MacDonald et al., 2011; van Spronsen, van Rijn, Bekhof, Koch, \& Smit, 2001). The combination of the amino acid mixtures with a rigorously controlled diet tailored to individual's needs optimises protein intake and amino acids profile of the diet.

Among all the dishes analysed in this study, boiled rice and boiled potatoes contained the highest levels of Phe $(158.5 \mathrm{mg} /$ $100 \mathrm{~g}$ and $62.5 \mathrm{mg} / 100 \mathrm{~g}$, respectively). The highest levels of Tyr were found in stuffed potato and in roast potato with vegetables ( $36.2 \mathrm{mg} / 100 \mathrm{~g}$ and $41.2 \mathrm{mg} / 100 \mathrm{~g}$, respectively). Phe and Tyr were found at the lowest concentration in desserts (sweet vermicelli: $3.9 \mathrm{mg}$ Phe/100 g and $2.6 \mathrm{mg}$ Tyr/100 g; biscuits cake: $8.6 \mathrm{mg}$ Phe/100 g and $1.4 \mathrm{mg}$ Tyr/100 g).

Table 2 shows that boiled rice (13) significantly differed $(p<0.05)$ from other foods because of its high content of Pro, Met, Gly and Phe.

It was noticed that protein level was highly correlated with the content of specific amino acids (Fig. 2), namely His, Leu, Ile, and Phe ( $r$ P 0.9140). In this way, it was possible to predict His, Leu, Ile, and Phe content with a high level of confidence based on the protein without need to resort to a more complex analysis as liquid chromatography. This is due to the fact that amino acids are not equally distributed among proteins. Moreover, the amount of a certain amino acid per $1 \mathrm{~g}$ of protein is also variable with food. Considering the case of Phe, for instante, $5 \mathrm{mg} / \mathrm{g}$ of protein were found in sweet vermicelli (12) while boiled rice (13) contained $50 \mathrm{mg} / \mathrm{g}$ of protein. All the remaining dishes presented intermediate values $(12-33 \mathrm{mg} / \mathrm{g}$ of protein). It is described that the assumption that $1 \mathrm{~g}$ of protein contains $5 \%$ or $50 \mathrm{mg}$ phenylalanine is not applicable to fruits and vegetables since they contain lower values of Phe per g of protein compared to cereals or natural animal-based foods (Weetch \& MacDonald, 2006). Indeed, our findings go in accordance with that remark.

In general, no correlation was observed between Phe and Tyr content $(r=0.5268)$, but a high correlation was found between 

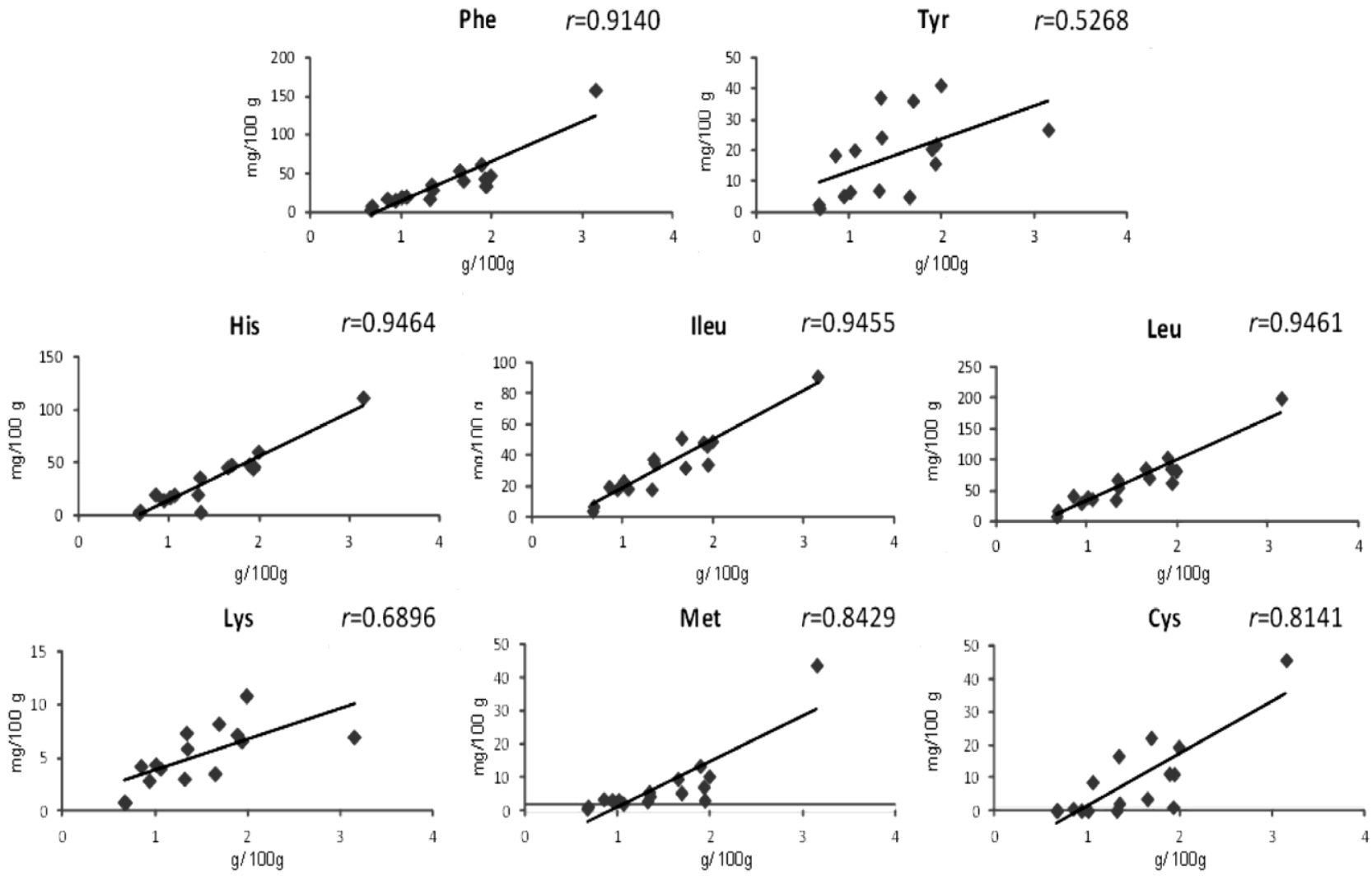

Thr $\quad r=0.1360$
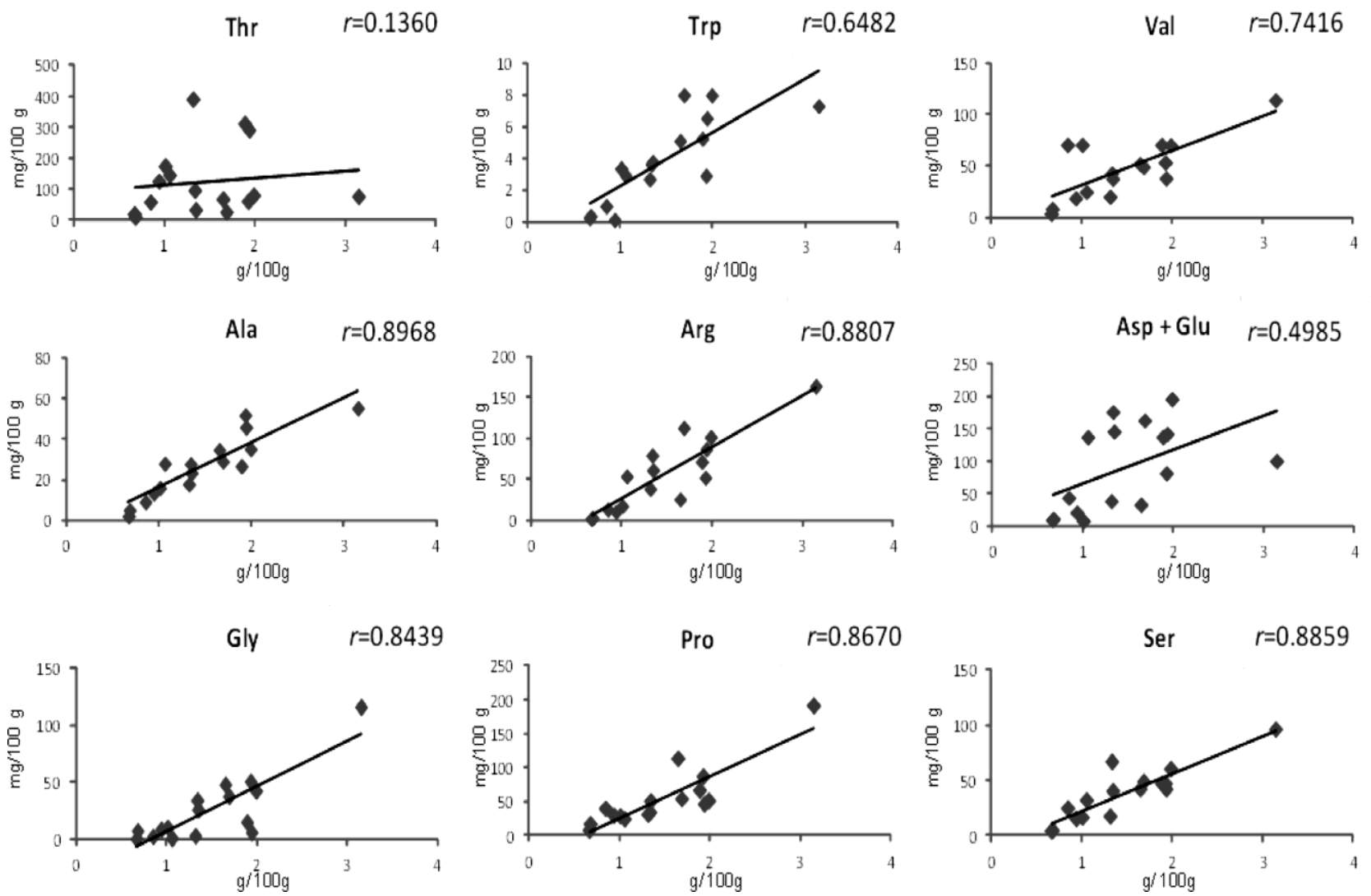

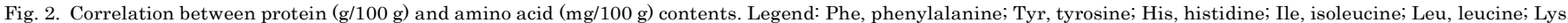

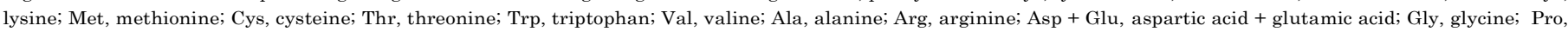
proline; Ser, serine. 


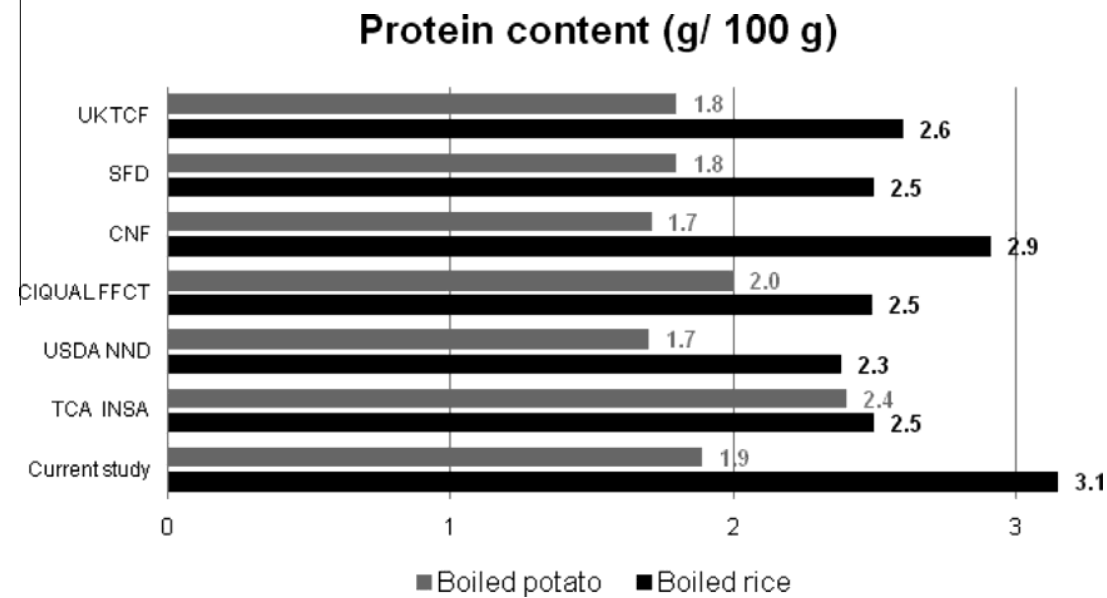

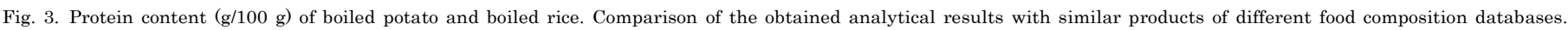

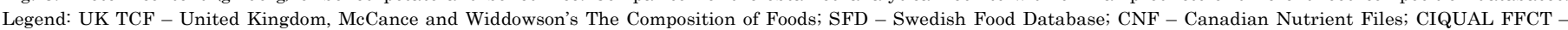

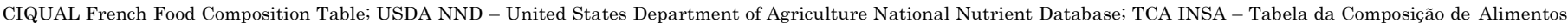
Instituto Nacional de Saúde Dr. Ricardo Jorge (Portugal).

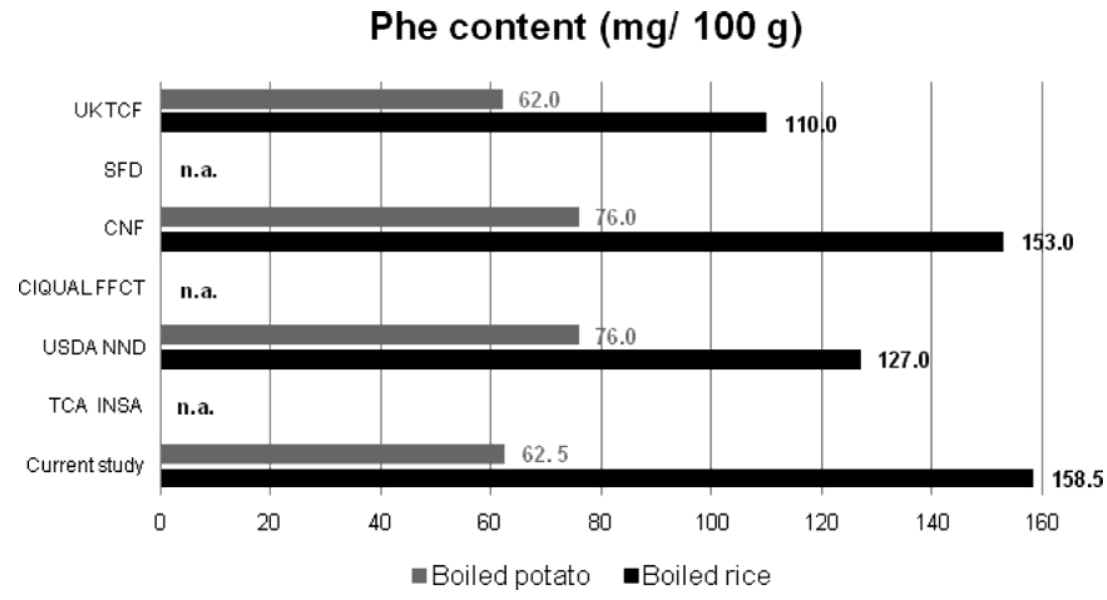

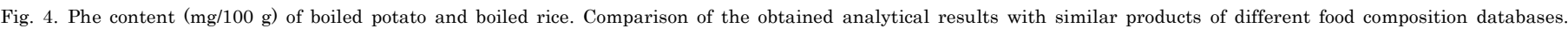

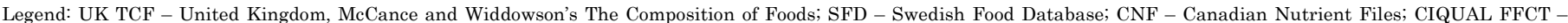

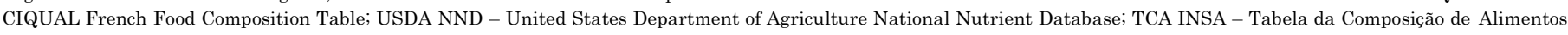
Instituto Nacional de Saúde Dr. Ricardo Jorge (Portugal); n.a. - data non available.

Phe and the following amino acids: Leu, Met, Ile, Pro, His, Gly (correlation coefficients: $0.9842,0.9811,0.9464,0.9434,0.9275$ and 0.9132 , respectively).

Due to the scarcity of information regarding amino acid composition of two basic daily foods used by PKU patients in Portugal rice and potato, recipes 13 and 14, respectively - we intentionally included these items in the list of recipes as single boiled foods. When there is no information available about the amino acid composition of foods, it is usual to search for the information in available other FCD to plan patients' diets. Thus, analytical results for protein and Phe content of boiled rice and boiled potatoes were compared with information described in other international FCD (Figs. 3 and 4, respectively).

Slight deviations were found and may be attributed to factors already described, namely natural variability of nutritional composition of the foods, variability within species, effects of cooking methods, and samples analysis methods among others. Nevertheless, the results obtained for potato protein $(1.9 \mathrm{~g} / 100 \mathrm{~g})$ were within the range of the six FCD used for comparison (1.7-2.0 g/ $100 \mathrm{~g})$. But, as far as boiled rice was concerned, our results
(3.1 mg/100 g) were slightly higher than those found in the other FCD (2.4-2.9 mg/100 g), which could be due to not only to the type of rice analysed (carolino) but also to the cooking procedure, which influences the final moisture content.

The lack of information concerning Phe is clear as only three of the six FCD used provided any information, namely the UK TCF, the CFN and the USDA NND (Fig. 4). For the two basic daily foods more used by PKU patients in Portugal, our results were different to those offered by the other FCD; our Phe levels were lower in boiled potatoes (except when comparing with UK TCF FCD) and higher in boiled rice. Indeed, for boiled potato, some FCD overestimate the amount of Phe by about $13.6 \mathrm{mg} / 100 \mathrm{~g}$ (USDA NND and CNF) and the UK TCF underestimate it by $0.5 \mathrm{mg} / 100 \mathrm{~g}$. All of the FCD underestimated Phe in boiled rice by $48.5 \mathrm{mg} / 100 \mathrm{~g}$ (UK TCF), $31.5 \mathrm{mg} /$ $100 \mathrm{~g}$ (USDA NND), and $5.5 \mathrm{mg} / 100 \mathrm{~g}(\mathrm{CNF})$, respectively.

Although there is substantial variation in dietary guidelines among countries and dietary management between treatment centers (Ahring et al., 2009; Blau et al., 2010), daily meals are calculated on an internally recognised Phe exchanges system. One unit corresponds to a portion of food in grams that contains a fixed 
amount of Phe allowing patients to easily exchange foods of equivalent Phe content (Ahring et al., 2009). Based on this, the results obtained are of great importance since they have direct impact on the amount of food patients can consume safely.

PKU patients' diets have to be carefully adapted and individually planned to assure the provision of the adequate amounts of all nutrients, in order to promote good health and prevent any possible nutritional deficiency. It is clear that most literature refers to the nutritional composition of isolated foods, only occasionally describing the effect of cooking methods. It is important to consider that foods can be consumed alone or combination in a single recipe, using preparation and processing methods that can affect overall composition of the final meal. Therefore, it is important to study the composition of prepared dishes for PKU patients and to obtain real data for protein and amino acid composition, with particular reference to Phe content. The use of FCD to plan recipes and meals for PKU patients is useful, but needs to be used carefully, and the results reflect deviations observed in analytical results. This is of utmost relevance because the diet can be planned better with more accurate data on Phe content of foods.

\section{Acknowledgements}

The authors thank to Centro de Genética Médica Doutor Jacinto de Magalhães, INSA IP Porto, Portugal, for gently providing all the dietetic low protein and low-Phe products used in the current study.

Rita C. Alves is grateful to Fundação para a Ciência e a Tecnologia for a post-doctoral research grant (SFRH/BPD/68883/2010) financed by POPH - QREN - Tipologia 4.1 - Formação Avançada, subsidized by Fundo Social Europeu and Ministério da Ciência, Tecnologia e Ensino Superior.

This work has been supported by Fundação para a Ciência e a Tecnologia through grant no. PEst-C/EQB/LA0006/2011.

\section{References}

Ahring, K., Bélanger-Quintana, A., Dokoupil, K., Ozel, H. G., Lammardo, A. M., MacDonald, A., et al. (2009). Dietary management practices in phenylketonuria across European centres. Clinical Nutrition, 28, 231-236.

Almeida, M. F. (1995). PKU Comer bem. sem fazer mal (Vol. 1). Porto: Instituto de Genética Médica Doutor Jacinto de Magalhães.

Almeida, M. F. (2001). PKU Comer bem. sem fazer mal (Vol. 2). Porto: Instituto de Genética Médica Doutor Jacinto de Magalhães.

ANSES (Agence nationale de sécurité sanitaire de l'alimentation, de l'environnement et du travail). Composition nutritionnelle des aliments, Table Ciqual 2012. URL: http://www.anses.fr/TableCIQUAL/.

Bélanger-Quintana, A., Burlina, A., Harding, C. O., \& Muntau, A. C. (2011). Up to date knowledge on different treatment strategies for phenylketonuria. Molecular Genetics and Metabolism, 104, S19-S25.

Blau, N., Bélanger-Quintana, A., Demirkol, M., Feillet, F., Giovannini, M., MacDonald, A., et al. (2010). Management of phenylketonuria in Europe: Survey results from 19 countries. Molecular Genetics and Metabolism, 99, 109-115.

Blau, N., Hennermann, J. B., Langenbeck, U., \& Lichter-Konecki, U. (2011). Diagnosis, classification, and genetics of phenylketonuria and tetrahydrobiopterin (BH4) deficiencies. Molecular Genetics and Metabolism, 104, S2-S9.
Blau, N., van Spronsen, F. J., \& Levy, H. L. (2010). Phenylketonuria. Lancet, 376,14171427.

Bremer, H. J., Anninos, A., \& Schulz, B. (1996). Amino acid composition of food products used in the treatment of patients with disorders of the amino acid and protein metabolism. European Journal of Pediatrics, 155, S108-S114.

Centerwall, S. A., \& Centerwall, W. R. (2000). The discovery of phenylketonuria: The story of a young couple, two retarded children, and a scientist. Pediatrics, 105 89-103.

de Groot, M. J., Hoeksma, M., Blau, N., Reijngoud, D. J., \& van Spronsen, F. J. (2010). Pathogenesis of cognitive dysfunction in phenylketonuria: Review of hypotheses. Molecular Genetics and Metabolism, 99, S86-S89.

Demirkol, M., Gizewska, M., Giovannini, M., \& Walter, J. (2011). Follow up of phenylketonuria patients. Molecular Genetics and Metabolism, 104, S31-S39.

Feillet, F., \& Agostoni, C. (2010). Nutritional issues in treating phenylketonuria. Journal of Inherited Metabolic Disease, 33, 659-664.

Fountoulakis, M., \& Lahm, H. W. (1998). Hydrolysis and amino acid composition analysis of proteins. Journal of Chromatography A, 826, 109-134.

Health Canada. The Canadian Nutrient File, 2010. URL: $\leq$ http://www.hc-sc.gc.ca/fn an/nutrition/fiche-nutri-data/cnf_downloads-telechargement_fcen-eng.php. Accessed 01.08.2012.

Instituto Nacional de Saúde Doutor Ricardo Jorge (INSA). Tabela de Composição dos Alimentos-INSA, 2006. URL:<http://www.insa.pt/sites/INSA/Portugues/Areas Cientificas/AlimentNutricao/AplicaoesOnline/TabelaAlimentos/PesquisaOnline/ Paginas/PorPalavraChave.aspx. Accessed 01.08.2012.

MacDonald, A., Rocha, J. C., van Rijn, M., \& Feillet, F. (2011). Nutrition in phenylketonuria. Molecular Genetics and Metabolism, 104, S10-S18.

Mallolas, J., Milà, M., Lambruschini, N., Cambra, F. J., Campistol, J., \& Vilaseca, M. A. (1999). Biochemical phenotype and its relationship with genotype in hyperphenylalaninemia heterozygotes. Molecular Genetics and Metabolism, 67, 156-161.

National Food Agency. The Swedish Food Database, 2010. URL: http://www7.slv.se/ Naringssok/.

Navarro, J. L., Aristoy, M., \& Izquierdo, L. (1984). Quantitative-analysis of aminoacids in fruit juices and soft drinks by high-performance liquidchromatography. Revista De Agroquimica Y Tecnologia De Alimentos, 24, 85-93.

Paramas, A. M. G., Barez, J. A. G., Marcos, C. C., Garcia-Villanova, R. J., \& Sanchez, J. S. (2006). HPLC-fluorimetric method for analysis of amino acids in products of the hive (honey and bee-pollen). Food Chemistry, 95, 148-156.

Paul, A. A., McCance, R. A., Southgate, D. A. T., \& Russell, J. (1980). First supplement to McCance and Widdowson's The composition of foods: amino acids, $m g$ per $100 \mathrm{~g}$ food, fatty acids, g per $100 \mathrm{~g}$ food. London: H. M. Stationery Off.

Rocha, J. C., \& Martel, F. (2009). Large neutral amino acids supplementation in phenylketonuric patients. Journal of Inherited Metabolic Disease, 32, 472-480.

Scriver, C. R., \& Kaufman, S. (2001). Hyperphenylalaninemia: Phenylalanine hydroxylase deficiency (8th ed.). New York: McGraw-Hill.

Smith, I., \& Lee, P. (2000). The hiperphenylalaninaemias. In: S. J.-M. Fernandes, J. Van den Berghe (Eds.), Inborn Metabolic Diseases: Diagnosis and Treatment, (pp. 171184). New York: Springer.

Tontisirin, K., MacLean, W. C., \& Warwick, P. (2003). Food energy: Methods of analysis and conversion factors: Report of a technical workshop, Rome, 3-6 December 2002. Rome: Food and Agriculture Organization of the United Nations.

United States Department of Agriculture. National Agricultural Library. USDA National Nutrient Database for Standard Reference. Nutrient Data Laboratory, 2011. URL: <http://www.ars.usda.gov/ba/bhnrc/ndl. Accessed 01.08.2012>.

Van Spronsen, F. J., \& Enns, G. M. (2010). Future treatment strategies in phenylketonuria. Molecular Genetics and Metabolism, 99, S90-S95.

Van Spronsen, F. J., van Rijn, M., Bekhof, J., Koch, R., \& Smit, P. G. A. (2001). Phenylketonuria: Tyrosine supplementation in phenylalanine-restricted diets. American Journal of Clinical Nutrition, 73, 153-157.

Weetch, E., \& MacDonald, A. (2006). The determination of phenylalanine content of foods suitable for phenylketonuria. Journal of Human Nutrition \& Dietetics, 19, $229-236$.

Yust, M. M., Pedroche, J., Girón-Calle, J., Vioque, J., Millán, F., \& Alaiz, M. (2004). Determination of tryptophan by high-performance liquid chromatography of alkaline hydrolysates with spectrophotometric detection. Food Chemistry, 85, 319320 . 